\title{
Türkiye'de kadına yönelik aile içi şiddet ve kadın cinayetleri
}

\author{
Gülsen Erden ${ }^{1}$, Serel Akdur ${ }^{2}$
}

\author{
Anahtar kelimeler \\ aile içi şiddet, kadına \\ yönelik aile içi şiddet, \\ kadın cinayetleri, şiddet, \\ kadin
}

\section{Key words}

domestic violence, domestic violence against women, murders of women, violence, women

\begin{abstract}
Öz
Türkiye'de kadına yönelik aile içi şiddetin ve şiddetin en uç noktası olan kadın cinayetlerinin gün geçtikçe arttığı görülmektedir. Bu çalışmada, kadına yönelik aile içi şiddet karşısında gerekli önlemlerin alınması ve kadın cinayetlerinin durdurulması adına, kadın cinayetlerindeki fail ve maktullerin belirli özelliklerinin saptanması amaçlanmıştır. Çalışmada, şiddetten ölen kadınlar için dijital anıt kapsamında oluşturulmuş bir internet sitesinde arşivlenen (www.anitsayac.com) ve Ocak 2014 - Nisan 2015 tarihleri arasında gerçekleşen kadın cinayetleri incelenmiştir. 335 kadın maktul ve 318 erkek failin sosyodemografik bilgileri, faillerin geçmiş suç öyküleri ve psikiyatrik bozukluklarına dair bilgiler ile işlenen cinayete dair bilgiler tespit edilmiştir. Kadın cinayetlerinde faillerin büyük bir kısmının kadının partneri olduğu, fail ve maktullerin çoğunlukla 50 yaşın altında oldukları ve vasıfsız işte çalıştıkları görülmüştür. Cinayet sebebi olarak tartışma, kıskançlık ve aldatma şüphesi ön plana çıkmıştır. Bu çalışma sonucunda eğitim düzeyinin düşük olması, ekonomik sıkıntılar ve ataerkil toplum özelliğinin kadın cinayetlerinde önemli risk faktörleri olduğu görülmüştür. Bu risk faktörlerini belirlemenin, gün geçtikçe artan kadın cinayetlerini önlemede önemli olduğu düşünülmektedir.
\end{abstract}

\begin{abstract}
Domestic violence against women and murders of women in Turkey

There is an increasing trend in domestic violence against women and murders of women in Turkey. The purpose of this study is to evaluate the particular characteristics of perpetrators and victims in order to be able to take necessary preventive actions for domestic violence against women and stop murders of women. In the present study, murders of women (from January 2014 to April 2015 archived on a website (anitsayac.com) as a digital memorial were examined. Sociodemographic information of 335 female murder victims and 318 male perpetrators, perpetrators' crime and psychiatric history of, and homicide characteristics were identified. Findings revealed that most of the perpetrators and victims are younger than 50 years and unqualified workers and perpetrators are mostly the victim's partner. Verbal arguments, romantic jealousy and doubt of partner's unfaithfulness were the major murder reasons. Low educational and economical levels and patriarchal gender system were identified as risk factors for women homicides. This attempt to identify risk factors is considered to be important for preventing the increasing prevalence of women homicides.
\end{abstract}

Erden, G. ve Akdur, S. (2018). Türkiye'de kadına yönelik aile içi şiddet ve kadın cinayetleri. Klinik Psikoloji Dergisi, 2(3), 128-139

\footnotetext{
$\triangle$ Serel Akdur·sakdur@ankara.edu.tr

${ }^{1}$ Prof. Dr., ${ }^{2}$ Arş. Gör., Ankara Üniversitesi, Dil ve Tarih

Coğrafya Fakültesi, Psikoloji Bölümü, Sıhhiye/Ankara, 06100.
}

Geliş tarihi: 25.05.2018

Kabul tarihi: 08.09.2018 
Kadına yönelik şiddet kadının elinden yaşama hakkının, onurunun, güvenliğinin, özgürlüğünün ve bedensel bütünlüğünün, sırf kadın olduğu için alınması durumudur (Ankara Barosu Kadın Hakları Merkezi, 2008). Kadınlar fiziksel șiddet (kadına fiziksel olarak zarar vermek), cinsel șiddet (kadını istemediği cinsel davranışlara zorlamak), duygusal şiddet (sözel olarak yıpratıc1 davranıp psikolojik anlamda baskı uygulamak) ve ekonomik şiddet (kadının ekonomik özgürlüklerine müdahale etmek) olmak üzere farklı türlerde şiddete maruz kalmaktadırlar (Ankara Barosu Kadın Hakları Merkezi, 2008; Kadının Statüsü Genel Müdürlüğü [KSGM], 2008, 2013). Kadınlar aile içinde kendilerinden fiziksel olarak güçlü olan erkekler tarafindan bu şiddet türlerine maruz kalırken, erkeklerin şiddet uygulama nedenleri genellikle kadını kontrol etmek, cezalandırmak, korkutmak, kadına karş1 güç gösterisinde bulunmak ve baskı kurmak olmaktadır (Page ve İnce, 2008).

Birincil mağdurun kadın olduğu eş şiddetine ilişkin yurtiçi ve yurtdışı alanyazını incelendiğinde, her ne kadar ülkeden ülkeye ya da ülkedeki yerleşim birimlerine göre farklılık gösterse de şiddetin kaç1nılmaz olarak varlığını sürdürdüğü görülmektedir (örn., Alhabib, Nur ve Jones, 2010; Dery ve Diedong, 2014; Özgentürk, 2015; Pandey ve Nath, 2014). Bu sonuca ulaşmamızı sağlayan kapsamlı çalışmalardan biri, Dünya Sağlık Örgütü (WHO, 2005) tarafından gerçekleştirilmiştir. Bu araştırmada on farklı ülkedeki (Bangladeş, Brezilya, Etiyopya, Japonya, Namibya, Peru, Samoa Adaları, Sirbistan-Karadağ, Tayland, Tanzanya Cumhuriyeti) yaklaşık 24 bin kadından maruz kaldıkları şiddet hakkında veri toplamıştır. Yayınlanan raporda, kadınların hayatlarının bir bölümünde eşleri tarafından fiziksel şiddete uğrama oranlarının \%13 ile \%61, cinsel şiddete uğrama oranlarının $\% 6$ ile $\% 59$, duygusal şiddete uğrama oranlarının ise \% 20 ile \%75 arasında değiştiği belirtilmektedir. Fiziksel ve cinsel şiddete uğrama sıklığı, ülkelere ve yerleşim birimlerine göre incelendiğinde, şiddetin en yüksek Etiyopya'nın kırsal kesiminde (\%71), en düşük Japonya'nın şehir kesiminde (\%15) olduğu görülmüştür (WHO, 2005). Kültürel farklılıklara, sosyoekonomik düzeye ve yerleşim yerlerine göre sıklığ 1 geniş bir aralıkta değişim gösterse de eş şiddeti varlığını sürdürmeye devam etmektedir.

Dünya Sağlık Örgütü (WHO, 2013) tarafindan gerçekleştirilmiş başka bir kapsamlı çalışmada 19942011 yılları arasında eşi ve eşi dışındaki bireylerin kadına uyguladığı şiddetin incelendiği araştırmalar gözden geçirilmiş ve 56 ülkeden toplam 347.605 kadından toplanmış veriler değerlendirilmiştir. Araştırma raporuna göre, kadınların \%35'i erkekler tarafindan fiziksel ve/veya cinsel şiddete uğramakta ve şiddeti uygulayanlar genellikle eşleri (\%30) olmaktadir.
Ülkemizde kadına yönelik aile içi şiddet konusunun kamuoyu ve devletin gündeminde bir sorun alanı olarak yer almas1, 1980'li yıllardan itibaren kadın hareketlerinin çabaları sonucunda olmuştur. Kadına yönelik aile içi şiddetle mücadele etmek için oluşturulacak programların etkililiğini arttırmak için Dünya Sağlık Örgütü'nün (2005) gerçekleştirmiş olduğu çalışma örnek alınarak, 2008 yılında ülkemizde bir çalışma yapılmıştır. "Türkiye'de Kadına Yönelik Aile İçi Şiddet Araştırması" adı ile yürütülen kapsamlı araştırmanın sonuçlarına göre ülke genelinde yaşamının herhangi bir döneminde fiziksel şiddete uğrayan kadınların oranı $\% 39$, cinsel şiddete uğrayanların ise \%15'tir. Kadınların \%42'si, hayatlarının herhangi bir döneminde fiziksel veya cinsel şiddete maruz kalmıştır. Diğer bir deyişle, Türkiye'de her 10 kadından 4'ü eşi veya birlikte olduğu kişi/kişiler tarafindan fiziksel şiddete ve/veya cinsel şiddete maruz kalmıştır (KSGM, 2009). Ek olarak, cinsel şiddetin yaşandığı ilişkilere çoğunlukla fiziksel şiddet de eşlik etmektedir. Yaşamının herhangi bir döneminde duygusal şiddete uğrayan kadınların oranı $\% 44$, çalışmasının engellenmesi ya da işten ayrılmaya zorlanması şeklinde ekonomik şiddete uğrayan kadınların oranı ise \%23'tür (KSGM, 2009). Bu tarihten itibaren kadına yönelik şiddet konusunda ülkemizde meydana gelen değişikliği ortaya koymak amacıyla aynı çalışma 2014 yılında yeniden yapılmıştır (KSGM, 2015). $\mathrm{Bu}$ araştırmada yaşamının herhangi bir döneminde şiddete maruz kalma sıklığ incelendiğinde, 2008 yılına kıyasla fiziksel şiddete uğrayan kadınların oranının \%36'ya, cinsel şiddete uğrayanların oranının $\% 12$ 'ye, fiziksel veya cinsel şiddete uğrayanların oranının \%37'ye düştüğü görülmüştür. Ancak kadınların yaşamının herhangi bir döneminde duygusal şiddete maruz kalma sıklığının aynı oranda kaldığı (\%44), ekonomik şiddete maruz kalma sıklığının ise \%24'e yükseldiği saptanmıştır (KSGM, 2015).

Yurt içi ve yurtdışı alanyazınında, şiddet olaylarının incelendiği araştırmalar şiddeti uygulayan faile ya da şiddet mağduruna odaklanmaktadır (örn., Babu ve Kar, 2009; Caetano, Vaeth ve Ramisetty-Mikler, 2008; Yaman Efe ve Ayaz, 2010). Özellikle şiddete uğrayan kadınların yaşı, eğitim düzeyi, çalışma durumu, ilişki durumu gibi sosyodemografik özellikler aile içi şiddette risk faktörü olarak ele alınmaktadır (örn., WHO, 2005; KSGM, 2009; 2015). Risk faktörlerini birey, ilişki, topluluk ve toplum düzeyinde ele alan "ekolojik model" (Heise, 1998) aile içi şiddeti anlamada büyük önem taşımaktadır. Bu modele göre birey düzeyinde önemli risk faktörleri kadın ve erkek için genç yaşta olmak, eğitim düzeyinin düşük olmas1, düşük gelire sahip olmak, kadın için eşinden ayrı olmak, erkek için ise işsiz olmaktır. Ruh sağlığı açısından erkekte antisosyal kişilik bozukluğunun, kadinda depresyonun olması ve her iki tarafin da yasadışı ilaç ve aşırı alkol kullanımının olması aile içi 
şiddet riskini arttırmaktadır. Ayrıca şiddetin her iki taraf için kabul edilen bir eylem olması, geçmişte de erkeğin istismar edici, kadının istismar mağduru olması birey düzeyinde değerlendirilen aile içi şiddet için risk faktörlerindendir (Capaldi, Knoble, Shortt ve Kim, 2012; WHO, 2012; Heise, 1998). İlișki düzeyinde incelendiğinde, çiftin arasında eğitim düzeyi açısından uyumsuzluk olduğu, ailenin ataerkil yapıda olduğu, aile içi geçimsizliğin ve erkeğin başka eşlerinin de olduğu durumların aile içi şiddet için risk faktörü olduğu görülmektedir. Her iki tarafın da geleneksel cinsiyet rollerini benimsemesi, erkeğin arkadaşlarının da şiddeti meşrulaştırması, kadının ve ailenin çevreden izole olması, toplumsal yaptırımın düşük olması ise topluluk düzeyindeki önemli risk faktörleridir (Heise, 1998). Bu çevreler yoksulluk ve işsizlik oranının yüksek oranda, yüksek eğitim düzeyine sahip kadınların düşük oranda olduğu, erkeklerin otonomisinin yüksek, kadınların otonomisinin düşük olduğu çevreler olarak tanımlanmaktadır (WHO, 2012). Son olarak aile içi şiddet risk faktörleri toplum düzeyinde incelendiğinde, hem kadın hem erkek için cinsiyete bağlı sosyal normların olması (örneğin, erkeklik kavramının hâkimiyet ve öfkeyle ilişkilendirilmesi), erkeğin kadının sahibi olarak görülmesi, şiddetin etkin bir çatışma çözme şekli olarak kabul edilmesi ve şiddeti destekleyen sosyal normlar olmas1 dikkat çekmektedir (WHO, 2012; Heise, 1998). Bu risk faktörleri aile içi şiddetin nedenini anlamamıza yetmese de olası risk gruplarına geniş bir çerçeveden bakabilmemizi mümkün kılmakta ve bu olgunun önlenebilmesi için büyük önem taşımaktadır.

Yukarıda yer alan risk faktörlerinin yanı sıra ergenlik döneminde kişilerarası ilişkilerin, romantik deneyimlerin ve yakın ilişkilerin doğasına dair beklentilerin ailede öğrenildiği göz önünde bulundurulduğunda, aile içi şiddetin de ailede öğreniliyor olabileceği yaygın bir görüştür. Çocukluk döneminde anne baba arasındaki şiddete tanık olmak, çocuklara hem kurban hem de fail rollerini öğreterek eş şiddetinin nesilden nesile aktarılmasina sebep olmaktadır (Ehrensaft ve ark., 2003). Straus ve Gelles (2006), çocukluk döneminde anne babası arasındaki fiziksel şiddete tanık olanların, gelecekte eşlerine şiddet uygulama olasılıklarının üç kat daha fazla olduğunu belirtmektedir. Diğer bir deyişle, aile içinde şiddeti öğrenen çocuğun, kendi ailesini kurduğunda aynı davranışı sergileme olasılığı daha yüksektir.

Görüldüğü gibi kadına yönelik aile içi şiddet fark11 sosyoekonomik düzeyle dünya genelinde varlığını sürdüren bir olgu olarak karşımıza çıkmakta ve duygusal şiddetten silah ve bıçakla yaralama ya da öldürmeye kadar giden pek çok davranışı içermektedir. Burada gelinebilecek ve dönüşü olmayan son nokta cinayettir. Kadın cinayeti (femicide), kadının sırf kadın olduğu için, kadın olmanın getirdiği toplumsal roller nedeniyle öldürülmesine işaret etmektedir
(Russell, 2008; Taşdemir Afşar, 2016). Kadın cinayetlerinde erkekleri cinayet işlemeye güdüleyense nefret, aşağılama, haz veya kadına sahip olma duygusu olmaktadır (Caputi ve Russell, 1990). Alanyazında kadınların çoğunlukla eşi ya da eski eşi tarafından öldürüldüğü bulgusu dikkat çekmektedir. Eş cinayetlerini inceleyen 1982-2011 yılları arasında 66 ülkede yapılmış olan 227 araştırma sonucunun değerlendirildiği bir meta analiz çalışmasında, kadınların \%38'inin katilinin eşi ya da eski eşi (kocası, sevgilisi, eski kocası ya da eski sevgilisi) olduğu sonucuna ulaşılmıştır. Buna karşın eşi ya da eski eşi tarafından öldürülmüş erkeklerin oranı bunun altıda biri (\%6) kadardır (Stöckl ve ark., 2013). Eşi tarafindan öldürülmüş erkeklerin kadınlardan daha az olduğunu gösteren başka çalışmalar da mevcuttur (örn., Adinkrah, 2008; Puzone, Saltzman, Kresnow, Thompson ve Mercy, 2000). Ülkemiz açısından bakıldığında, kadın cinayeti verilerinin yayınlandığ 1 kapsamlı bir rapor bulunmadığ 1 ancak bu olguyu daha iyi anlamak için gazete haberleri ve otopsi raporlarının içerik analizinin yapıldığ 1 çalışmaların olduğu görülmektedir. Örneğin 2012 y1lı gazete haberlerinin içerik analizinin yapıldığı bir çalışmada kadın cinayetlerinin \%78.2'sinin kadının eşi ya da eski eşi tarafından işlendiği bulunurken (Çilingiroğlu ve Paksoy Erbaydar, 2016), 2011-2014 yılları arasında bir gazetede yayınlanan kadın cinayeti haberleri incelendiğinde bu oran \%54 olarak bulunmuştur (Yegen, 2014). Başka bir çalışmada 2000- 2012 yılları arasında 12 şehirde işlenmiş olan cinayetlerin otopsi raporları incelemesi sonucunda bu oran \%50 olarak bulunmuştur (Toprak ve Ersoy, 2017). Her ne kadar oranlar arasinda tutarsızlık olsa da ülkemizde de kadın cinayeti faillerinin büyük çoğunluğunun kadının eşi ya da eski eşi olduğu görülmektedir. Bunun yanı sıra pek çok kadın şiddetin son noktası olan ölümden önce tehdit, sindirme, cinsel şiddet gibi istismar türlerine veya kad1nın erkekten daha az güçlü ya da ulaşabileceği kaynakların daha kısıtlı olduğu yaşantılara maruz kalmaktadırlar (WHO, 2012). Amerika'da cinayete kurban giden 311 kadının yakınlarından bilgi toplanarak yapılan çalışmada kadınların \%66'sının öldürülmeden önce eşlerinden şiddet gördüğ̈̈ saptanmıştır (Sharps ve ark., 2001). Ülkemizde yapılan bir çalışmada ise eşi ya da eski eşi tarafından öldürülen kadınların \%30'unun öncesinde fiziksel ya da cinsel istismara uğradığ 1 belirtilmektedir (Toprak ve Ersoy, 2017).

Failler çoğu zaman ailenin namusunu korumak, bir geleneği uygulamak ya da dini inançlarına bağlı kalmak için kadınları öldürmektedir (WHO, 2012). Ülkemizde 2013 yılında eş ya da eski eş tarafından işlenmiş kadın cinayeti haberlerinin içerik analizi sonuçları bu cinayetlerin \%44'ünün tartışma ya da kavgalar, \%20'sinin kadının eşinden ayrılmak istemesi ve \%5'inin kıskançlı nedenleriyle işlendiğine 
işaret etmektedir (Atakay, 2014). Bu sonuçlar, tartışma ya da kavgaların içeriği bilinemediği için kıskançlık nedenini de içinde barındırıyor olabileceğine dikkat çekilerek tartışılmıştır. Toprak ve Ersoy (2017) ise çalışmasında eşi ya da eski eşi tarafından öldürülen kadınların \%45'inin kıskançlık, sadakatsizlik ve namus, \%21.3'ünün tartışma ve \%23.8'inin ayrılık nedenleriyle öldürülmüş olduğunu bildirmiştir. Karbeyaz, Akkaya ve Balcı (2013) da yaptıkları çalışmada kadınların büyük çoğunluğunun şiddetli geçimsizlik, tartışma, kıskançlık, aldatma şüphesi ve ayrılmak isteme nedenlerinden öldürüldüğünü ifade etmektedir. Ataerkil düzen doğrultusunda ailesi için çalışan ve para kazanan, güçlü ve cesur erkekler ailenin namusunu korumak için gerektiğinde şiddete de başvurabilmektedir (Taşdemir Afşar, 2016). Kadını öldürerek ailenin namusunu kurtarmak trajik olmasının yanı sıra kadınların ve kız çocuklarının ayrımcılığa maruz kaldığını ve bunun kültürel olarak kabul edildiğini göz önüne seren bir durumdur (WHO, 2012). Buradan hareketle, toplumsal rolü aile namusunu korumak olan erkeğin, eşinin ayrılmak istemesini, aldatılmayı ve eșini kıskanacağı bir durumun olmasını ailenin namus ve onuruna tehdit olarak görerek, bu tehdidi ortadan kaldırmak adına bu cinayeti işliyor olabileceği düşünülebilir.

Kadın cinayetlerinin yaygınlığı ve nedenleri göz önünde bulundurulduğunda, bu durumu engelleyebilmek adına risk gruplarının belirlenmesi büyük önem taşımaktadır. Bu çalışmada da alanyazında yer alan bulguların ekolojik model (Heise, 1998) üzerinden birey, ilişki, topluluk ve toplum düzeylerinde değerlendirilmesinin aydınlatıcı olacağı düşünülmektedir. İlk olarak birey düzeyinde fail ve maktullerin sosyodemografik özellikleri ülkemizdeki araştırma sonuçlarından yola çıkılarak değerlendirildiğinde, erkek faillerin 21- 40 yaşları arasında (Toprak ve Ersoy, 2017; Yılmaz, Kumral, Cantürk, Erkol ve Okumuş, 2015), kadın maktullerinse 20- 34 yaşları arasında olması (Çilingiroğlu ve Paksoy Erbaydar, 2016; Karbeyaz ve ark., 2013; Yegen, 2014) önemli bir risk faktörü olarak karşımıza çıkmaktadır. Bunun yanı sıra kadın maktullerin büyük çoğunluğunun ev kadını olduğu, faillerin ise çoğunlukla üniversite eğitimi gerektirmeyen işlerde çalıştıkları görülmektedir (Karbeyaz, Akkaya ve Balc1 2013; Toprak ve Ersoy, 2017; Yılmaz ve ark., 2015). Yurtdışında yapılan çalışmalarda da fail ve maktullerin çoğunlukla genç yaşta, düşük eğitim seviyesinde, işsiz ve iş aramayan ya da vasıfsız işte çalışan bireyler olduğu dikkat çekmektedir (Campbell ve ark., 2003; Echeburúa, Fernández-Montalvo, de Corral, P. ve LópezGoñi, 2009). Bunun yanı sıra birey düzeyindeki önemli bir diğer risk faktörüyse maktulün hamilelik döneminde şiddete maruz kalmasıdır (Campbell ve ark., 2003; WHO, 2012). Doğum sirasında ölen kadınların pek çoğunun hamilelik döneminde şiddete maruz kaldığ 1 ve bunun doğum sirasında ölmelerine neden olduğu ifade edilmektedir (WHO, 2012). Failin ateşli silahının olması, alkol ve uyuşturucu madde kullanması ve ruhsal bozukluğunun olması da birey düzeyindeki risk faktörlerindendir (Campbell, Glass, Sharps, Laughon ve Bloom, 2007; Campbell ve ark., 2003). Eş ya da eski eş tarafından işlenen kadın cinayetlerinde fail ve maktul arasındaki ilişkinin niteliği de önemlidir. Kadın cinayetlerinde ilişki düzeyindeki dikkate değer bir risk faktörü aile içi şiddettir (Campbell ve ark., 2007). Erkeğin kadına uyguladığı şiddetin sıklık ve yoğunluğunun artması, kadını cinsel ilişkiye zorlaması, silahla ya da öldürmekle tehdit etmesi ve 1srarlı takibi, kadının eşinden uzaklaşması, ayrılması ve kadının eski ilişkisinden çocuğunun da aynı evde yaşaması bu cinayetler için önemli risk faktörlerindendir (Campbell ve ark., 2003). Son olarak topluluk ve toplum düzeyinde değerlendirildiğinde, cinsiyet eşitsizliğinin fazla olması ve devletin sağlık, eğitim alanlarında yaptığı harcamaların azalmasının bu cinayetler için risk oluşturduğu görülmektedir (WHO, 2012).

Geniş bir bakış açısıyla incelendiğinde, eş cinayetlerini bir madalyon olarak düşünmek mümkündür. $\mathrm{Bu}$ madalyonun bir yüzünde şiddet mağduru kadınların öldürülmesi varken, diğer yüzünde daha nadir karşılaşılan kadınların mağdurken şiddet uygulayıcısını öldürüp fail olması yer almaktadır. Erkeklerin kadını kontrol etmek amacıyla uyguladığı tehdit ve şiddetin düzeyi zaman içinde artarken, bu süreçte kadın sürekli tehditle yüz yüzedir. Diğer bir ifadeyle, kadınlar uzun süre şiddete maruz kaldıktan sonra eşleri tarafından öldürülmektedir (Wormer ve Roberts, 2009). Ayrıca ataerkil toplum özelliğinin hakim olduğu bölgelerde kadınlar kendilerini eşlerine karşı koruyamamakta ve aile içi şiddete maruz kalmaktadırlar. Eşleri tarafından öldürülmüş kadınların sayısının erkeklerden daha fazla olmasının nedenlerinden biri bu düzen; bir diğeri ise kadınların fiziksel olarak erkeklerden çok daha güçsüz olmalarıdır (Adinkrah, 2008). Madalyonun diğer yüzündeyse sürekli şiddete maruz kalan, sindirilen ve korkutulan kadınların kendilerini korumak amacıyla, genellikle önceden planlanmış bir cinayetle eşlerini öldürmeleri yer almaktadır (WHO, 2012). Ülkemizde Lengerli'nin (2010) eşe yönelik işlenmiş şiddet suçu nedeniyle ceza infaz kurumlarında bulunan hükümlü ve tutuklularla yapmış olduğu bir çalışmada kadınların ve erkeklerin eşlerine yönelik şiddet uygulamasında etkisi olan faktörler incelenmiştir. Kadınlarda eşin alkol kullanım sıklığı ile eşten fiziksel ve cinsel şiddet görme sıklığ 1 arttıkça, aileden ve özel bir insandan (örneğin, flört, nişanlı, sözlü, akraba, komşu, doktor) algılanan sosyal destek azaldıkça daha sık şiddet uygulandığı sonucuna ulaşılmıştır. Erkeklerde ise arkadaşlardan algılanan sosyal destek azaldıkça uygulanan şiddet artmaktadır. Alkol kullanım sıklığ 1 
ile kadına yönelik aile içi şiddet arasındaki ilişkiyi destekleyen başka araştırmalar mevcut olmakla birlikte bu araştırmalarda sadece erkeklerin kadına uyguladığ1 şiddette alkolün etkisi incelenmiştir (örn., Caetano, Schafer ve Cunradi, 2001; Fals-Stewart, 2003; Sharps ve ark., 2001). Leonard ve Quingley (1997) aşırı alkol kullanımı ve aile içi şiddet arasındaki ilişkinin temelde üç modelle açıklanabileceğini ifade etmektedir. İlk modele göre, aşırı alkol kullanımı ve aile içi şiddet arasındaki bu ilişki, ikisiyle de ilişkili olan farklı bir faktörle (örneğin, genç yaşta olmak) açıklanmaktadır (Foran ve O'Leary, 2008). Bir diğer model, aşırı alkol kullanımının mutsuz, çatışmalı bir evlilik ortamına sebep olarak aile içi şiddeti etkileyebileceğini ifade etmektedir. Son model ise aşırı alkol kullanan erkeklerin, alkol zehirlenmesi nedeniyle daha fazla ya da daha ağır aile içi şiddet uyguladığını söylemektedir. Bu modele göre alkolün bilişsel süreçler üzerindeki etkisi veya sarhoşluğun bir mazeret olarak görülmesi şiddet uygulamayı kolaylaştırmaktadır (Leonard ve Quingley, 1997).

Aktarılan alanyazın bilgilerinden de anlaşılabileceği gibi, kadına yönelik aile içi şiddet ve kadın cinayeti olguları dünya genelinde araştırılan, nedenleri ve risk faktörleri aydınlatılmaya çalışılan konulardandır. Buradan hareketle, bu çalışmada 2014-2015 yılları arasında ülkemizde işlenen kadın cinayetlerinde fail ve maktullerin sosyodemografik özellikleri, fail ve maktul arasındaki ilişki ve cinayet nedenleri incelenerek kadın cinayetleri alanyazınına katkıda bulunulması amaçlanmıştır.

\section{YÖNTEM}

Bu çalışmada, 01.01.2014 ile 01.04.2015 tarih aral1ğında yayınlanan, erkekler tarafindan işlenmiş kadın cinayeti haberleri incelenmiştir. Cinayet haberlerine Anıt Sayaç'tan (2015), (www.anitsayac.com) ulaşılmıştır. Anıt Sayaç (2015), sayısı gün geçtikçe artan kadın cinayetlerine farkındalık yaratmak ve şiddet sonucu hayatını kaybeden kadınların anısını yaşatmak için dijital ortamda oluşturulmuş bir anıttır. $\mathrm{Bu}$ anıtta Türkiye'de uğradığı şiddet nedeniyle hayatını kaybeden kadınların isimleri ve cinayete ilişkin veriler haber kaynağıyla birlikte yer almaktadır ve internet sitesi günlük olarak güncellenmektedir. Bu çalışmada, Anıt Sayaç'ta (2015) yer alan veriler ve ilgili haber kaynakları incelenmiştir. İncelenen gazete haberlerinin güncel olması ve araştırmacının ulaşabilmesi bakımından incelenen cinayetler çalışmanın planlandığ tarih olan Nisan 2015 tarihinden önceki üç ay ve öncesindeki bir yılla sinırlandırılmıştır. Çalışmada Dünya Sağlık Örgütü'nün (2005) kadın sağlığı ve kadına yönelik aile içi şiddet araştırması ve Türkiye'de Kadına Yönelik Aile İçi Şiddet Araştırması (2008) dikkate alınarak kadınlar için yaş sınırı
15 olarak belirlenmiş ve 15 yaşın üstündeki kadın cinayeti haberleri çalışmaya dâhil edilmiştir.

Anıt Sayaç (2015) verilerine göre 2014 yilında 287, 2015 yılının ilk üç ayında ise 81 kadın öldürülmüştür. Çalışmada, dijital anıtta birden fazla kez ismi yazılan, 15 yaşın altında olan ve ölüm nedeni intihar olan maktuller dışarda bırakılmıştır. Söz konusu tarih aralığında 335 kadının, 318 erkek tarafından öldürüldüğü ve 14 failin birden fazla kadın cinayeti işlediği görülmüştür.

$\mathrm{Bu}$ çalışmada, fail ve maktullerin demografik özelliklerine (yaş ve meslek durumları), faillerin ulaşlabilen suç geçmişi ve psikiyatrik öykülerine, fail ve maktul arasındaki ilişkiye ve cinayetle ilgili bilgilere (cinayet nedeni ve cinayette kullanılan yöntem) dair betimsel istatistikler incelenmiştir.

\section{BULGULAR}

\section{Failin ve maktulün sosyodemografik özellikleri}

$\mathrm{Bu}$ çalışma kapsamında incelenen gazete haberlerinden ulaşılan 318 erkek fail ve 335 kadın maktulün yaş ve mesleklerine ilişkin bilgiler Tablo 1'de sunulmuştur.

Faillerin yaş gruplarına göre dağılımı incelendiğinde, \%3.1'inin 15-19 yaş arasında, \%8.5'inin 20-24 yaş arasında, \%10.7'sinin 25-29 yaş arasında, \%11.3'ünün 30-34 yaş arasında, \%11.3'ünün 35-39 yaş arasında, \%8.2'sinin 40-44 yaş arasında, \%5.3'ünün 45-49 yaş arasında, \%5.0'ının 50-54 yaş arasında, \%3.5'inin 55-59 yaş arasında, \%0.6'sının 60-64 yaş arasında, \%1.6'sının 65-69 yaş arasında, $\% 0.9$ 'unun 70-74 yaş arasinda, \%0.9'unun 75-79 yaş arasında ve \%1.6'sının 80-84 yaş arasında olduğu görülmektedir. 87 failin $(\% 27.4)$ yaş bilgisi gazete haberlerinde yer almamaktadır. Kadın cinayeti işlemiş ve yaş1 gazete haberlerinde belirtilmiş 231 failin yaş ortalaması 38.14 'tür $(S S=14.48)$. Cinayetleri işleyen erkeklerin büyük çoğunluğunun 25-39 yaşları arasında (\%33.3) olduğuna ulaşılmıştır.

Maktullerin yaş gruplarına göre dağılımı incelendiğinde ise, \%8.4'ünün 15-19 yaş arasında, \%12.2'sinin 20-24 yaş arasında, \%12.8'inin 25-29 yaş arasında, \%17.3'ünün 30-34 yaş arasında, \%10.1'inin 35-39 yaş arasında, \%12.2'sinin 40-44 yaş arasında, \%6.6'sının 45-49 yaş arasında, \%3.0'ının 50-54 yaş arasında, \%2.7'sinin 55-59 yaş arasında, \%1.8'inin 60-64 yaş arasında, \%0.9'unun 65-69 yaş arasında, \%0.9'unun 70-74 yaş arasında ve \%1.2'sinin 75-79 yaş arasında olduğu görülmektedir. 32 maktulün (\%9.9) yaş bilgisi belirtilmemiştir. Erkekler tarafindan öldürülmüş ve yaşı gazete haberlerinde belirtilmiş olan 302 maktulün yaş ortalaması 34.86 'dır $(S S=13.05)$. Bu bulgular değerlendirildiğinde, cinayete kurban giden kadınların büyük bir kısmının 20-34 yaşları arasında (\%42.3) olduğu gö- 
rülmektedir.

Tablo 1. Faillerin ve Maktullerin Sosyodemografik Özellikleri

\begin{tabular}{|c|c|c|c|c|}
\hline & \multicolumn{2}{|c|}{ Fail } & \multicolumn{2}{|c|}{ Maktul } \\
\hline & $\mathrm{n}$ & $\%$ & $\mathrm{n}$ & $\%$ \\
\hline \multicolumn{5}{|l|}{ Yaş grupları } \\
\hline $15-19$ & 10 & 3.1 & 28 & 8.4 \\
\hline $20-24$ & 27 & 8.5 & 41 & 12.2 \\
\hline $25-29$ & 34 & 10.7 & 43 & 12.8 \\
\hline $30-34$ & 36 & 11.3 & 58 & 17.3 \\
\hline $35-39$ & 36 & 11.3 & 34 & 10.1 \\
\hline $40-44$ & 26 & 8.2 & 41 & 12.2 \\
\hline $45-49$ & 17 & 5.3 & 22 & 6.6 \\
\hline $50-54$ & 16 & 5.0 & 10 & 3.0 \\
\hline $55-59$ & 11 & 3.5 & 9 & 2.7 \\
\hline $60-64$ & 2 & 0.6 & 6 & 1.8 \\
\hline $65-69$ & 5 & 1.6 & 3 & 0.9 \\
\hline $70-74$ & 3 & 0.9 & 3 & 0.9 \\
\hline $75-79$ & 3 & 0.9 & 4 & 1.2 \\
\hline $80-84$ & 5 & 1.6 & - & - \\
\hline Belirtilmemiş & 87 & 27.4 & 33 & 9.9 \\
\hline \multicolumn{5}{|l|}{ Meslek } \\
\hline $\begin{array}{l}\text { Üniversite } \\
\text { eğitimi } \\
\text { gerektiren }\end{array}$ & 3 & 0.9 & 12 & 3.6 \\
\hline $\begin{array}{l}\text { Güvenlik ve } \\
\text { koruma }\end{array}$ & 9 & 2.8 & 1 & 0.3 \\
\hline $\begin{array}{l}\text { Serbest } \\
\text { meslek }\end{array}$ & 10 & 3.1 & 4 & 1.2 \\
\hline Vasıflı işçi & 22 & 6.9 & 6 & 1.8 \\
\hline Vasıfsız işçi & 28 & 8.8 & 30 & 9.0 \\
\hline Emekli & 6 & 1.9 & - & - \\
\hline Öğrenci & 1 & 0.3 & 8 & 2.4 \\
\hline İşsiz & 6 & 1.9 & - & - \\
\hline Belirtilmemiş & 233 & 73.3 & 274 & 81.8 \\
\hline Toplam & 318 & 100.0 & 335 & 100.0 \\
\hline
\end{tabular}

Fail ve maktuller meslek gruplarına göre değerlendirilirken yaptıkları işlerin vasıflı olup olmaması, hizmet alanları, çalışanların eğitim düzeyleri gibi değișkenler göz önünde bulundurulmuștur. Buradan hareketle meslek grubu, üniversite mezunu meslek sahibi olanlar, güvenlik ve koruma işinde çalışanlar, serbest meslekleri olanlar, vasıflı işçiler, vasıfsız işçiler, emekliler, öğrenciler, işsizler ve iş durumu gazete haberlerinde belirtilmemiş olanlar olmak üzere 9 kategori altında değerlendirilmiştir.

Gruplar ayr1 ayr1 incelendiğinde, faillerin $\% 0.9$ 'unun üniversite eğitimi gerektiren meslek sahibi (örn., öğretmen, biyokimya uzmanı) olduğu görülmektedir. Güvenlik ve koruma işinde çalışanlar (örneğin, polis, güvenlik görevlisi) ise tüm faillerin $\% 2.8$ 'idir. Faillerin \%3.1'i işyeri sahibidir ve serbest meslek (örneğin, emlakçı, mağaza sahibi) çalışanıdır. Faillerin \% 6.9'u vasıflı işçi (örneğin, elektrik teknisyeni, sıhhi tesisatçı) \%8,8'i vasıfsı iş̧̧idir (örneğin, temizlik görevlisi, çoban). Faillerin \%1.9'u emekli, $\% 0.3$ 'ü öğrenci ve \%1.9'unun işsiz olduğu haberlerde belirtilmektedir. Gazete haberlerinde 233 failin (\%73.3) iş durumuna ve mesleğine dair bilgi gazete haberlerinde yer almamaktadır.

Aynı gruplama maktuller için yapıldığında, \% 3.6'sının üniversite eğitimi gerektiren meslek sahibi (örneğin, avukat, mühendis) oldukları görülmüştür. Maktullerin \%0.3'ü güvenlik ve koruma işinde çalışmış, \%1.2'si serbest meslek çalışanı, \%1.8'i vasıflı işçi (örneğin, kuaför, aşçı), \%9.0'1 vasıfsız işçidir (örneğin, temizlik görevlisi, bulaşıkçı). Maktullerin $\% 2.4$ 'ü ögrrencidir. Gazete haberlerinde 274 maktulün $(\% 81.8)$ iş durumuna ve mesleğine dair bilgiye yer verilmemiştir.

\section{Faillerin ruhsal bozuklukları ve geçmiş suç öyküleri}

Anıt Sayaç (2015) üzerinden Ocak 2014 - Nisan 2015 tarihleri arasında işlenmiş kadın cinayetlerine dair bilgiler incelendiğinde, faillerin bir kısmının ruhsal bozukluklarının olduğu görülmüştür. Faillerden 3 kişinin $(\% 0.9)$ şizofreni tanısının olduğunun, 3 kişinin (\%0.9) psikolojik sağlığının yerinde olmadığının belirtildiği ve 2 kişinin (0.6) psikiyatrik yardım aldığ 1 belirtilmektedir. 2 kişinin $(\% 0.6)$ ise uyuşturucu madde bağımlılığı olduğu bildirilmektedir. Toplamda 10 failin (\%3) psikolojik bozukluğunun olduğunun belirtildiği görülmektedir.

Faillerin geçmiş suç öykülerine bakıldığında ise 5 kişinin $(\% 1.5)$ adam yaralama, 2 kişinin $(\% 0.6)$ adam öldürme, 1 kişinin $(\% 0.3)$ silahlı kavgaya karışma, 2 kişinin $(\% 0.6)$ gasp/hırsılzlk, 2 kişinin $(\% 0.6)$ uyuşturucu madde ticareti yapma suçu olduğu görülmektedir. Bunların yanı sıra geçmișinde birden fazla suç işleyen failler de mevcuttur. 1 kişinin $(\% 0.3)$ gasp ve adam yaralama, 1 kişinin $(\% 0.3)$ adam yaralama, adam öldürme ve cezaevine uyuşturucu madde sokma, 1 kişinin (\%0.3) uyuşturucu madde satma ve hırsızlık, 1 kişinin $(\% 0.3)$ ise hırsızlık, uyuşturucu madde kullanmak ve adam yaralama suçu vardır. 7 kişinin (\%2.1) belirtilmemiş suçlardan cezaevinde olduğu görülmektedir. 1 kişinin $(\% 0.3)$ cinayet öncesinde denetimli serbestlikle cezaevinden çıktığ belirtilmektedir. Buradan hareketle 24 failin (\%7.2) geçmişte suç davranışının olduğu görülmektedir.

\section{Kadın cinayetlerinin bölgelere göre dağılımı}

Anıt Sayaç (2015) üzerinden Ocak 2014- Nisan 2015 tarihleri arasında işlenen kadın cinayetlerinin Türkiye İstatistiki Bölge Birimleri Sınıflamasına göre dağıll1$\mathrm{m} ı$ incelenmiştir. $\mathrm{Bu}$ konudaki sayısal veriler Tablo 2'de yer almaktadır.

Kadın cinayetlerinin büyük çoğunluğunun 60 cinayetle (\%17.9) İstanbul'da işlenmiş olduğu görülmektedir. İkinci sirada ise 56 cinayetle $(\% 16.7)$ 
Akdeniz Bölgesi, üçüncü sırada 50 cinayetle (\%14.9) Ege Bölgesi yer almaktadır. Diğer bölgeler incelendiğinde, kadın cinayetlerinin \%11.0'ının Güneydoğu Anadolu Bölgesinde, \%9.6'sının Doğu Marmara Bölgesinde, \%8.4'ünün Batı Anadolu Bölgesinde ve \%4.5'inin Orta Anadolu Bölgesinde ișlenmiş olduğu görülmektedir. Doğu Karadeniz, Kuzeydoğu Anadolu ve Bat1 Marmara bölgelerinin her birinde cinayetlerin \%3.3'ü işlenmiştir. $\mathrm{Bu}$ bölgeleri, \%3.0'lık oranla Ortadoğu Anadolu Bölgesi ve \%0.3'lük oranla KKTC izlemektedir.

Tablo 2. Kadın Cinayetlerinin Türkiye İBSS*'sine Göre Dağılımına Dair Frekans ve Yüzde Değerleri

\begin{tabular}{lcc}
\hline & $\mathrm{n}$ & $\%$ \\
\hline Bölgeler & 60 & 17.9 \\
İstanbul & 32 & 9.6 \\
Doğu Marmara & 11 & 3.3 \\
Batı Marmara & 50 & 14.9 \\
Ege & 28 & 8.4 \\
Batı Anadolu & 56 & 16.7 \\
Akdeniz & 15 & 4.5 \\
Orta Anadolu & 13 & 3.9 \\
Batı Karadeniz & 11 & 3.3 \\
Doğu Karadeniz & 11 & 3.3 \\
Kuzeydoğu Anadolu & 10 & 3.0 \\
Ortadoğu Anadolu & 37 & 11.00 \\
Güneydoğu Anadolu & 1 & 0.3 \\
KKTC & 335 & 100.0 \\
\hline Toplam &
\end{tabular}

"Türkiye IBBS; Türkiye İstatistiki Bölge Birimleri Sinıflamast.

\section{Cinayete İlişkin Özellikler}

Maktul ve fail arasındaki ilişkiye, cinayet nedenlerine ve cinayetin hangi yöntemle işlendiğine dair sayısal veriler Tablo 3'te sunulmuştur. Cinayetleri işleyen failler ile maktuller arasındaki ilişkiye bakıldığında, kadınların \%65.1'inin $(n=218)$ partneri tarafindan öldürüldüğü görülmektedir. Bu kadınların 139'u (\%41.6) resmi nikâhlı eşi, 16 kadın (\%4.8) eski eşi, 10 kadın (\%3) dini nikâhlı eşi tarafından öldürülmüştür. Kadınlardan 5'i (\%1.5) nişanlısı, 37'si (\%11.1) sevgilisi, 1'i (\%0.3) ayrılmış olduğu nişanlısı ve 10 'u (\%3) ayrıldığı sevgilisi tarafından öldürülmüştür. Görüldüğü gibi kadına yönelik aile içi şiddet uygula- yıcıları ve kadın cinayetlerinin failleri büyük oranda (\%65.1) kadının partneri olmaktadır.

Akrabaları veya hısımları tarafından öldürülen kadınlar ise tüm maktullerin \%20.9'unu $(n=70)$ oluşturmaktadır. Bu kadınların 6's1 (\%1.8) babası, 16's1 (\%4.8) erkek kardeși, 12'si (\%3.6) oğlu, 3’ü (\%0.9) üvey oğlu, 2'si (\%0.6) üvey babası, 3'ü (\%0.9) kuzeni, 1'i (\%0.3) yeğeni, 4'ü (\%1.2) eniştesi, 3'ü (\%0.9) kayınpederi, 3'ü (\%0.9) kayınbiraderi ve 9'u (\%2.7) damadı tarafindan öldürülmüștür. 1 kadın $(\% 0.3)$ aile meclisi tarafından, 7 kadın (\%2.1) ise yakınlık derecesi belirtilmemiş akrabaları tarafından öldürülmüştür.

Eş, akraba ve hısımların dışında öldürülen kadınlar ise tüm cinayetlerin \%14'ünü $(n=47)$ oluşturmaktadır. Bu gruptaki kadınların 2'si (\%0.6) arkadaşı, 5'i (\%1.5) komşusu, 15'i (\%4.5) tanıdığı belirtilen biri ve 6's1 (\%1.8) yabanc1 (maktul tarafindan tanınmayan) kimse tarafından öldürülmüştür. Kim tarafından öldürüldüğü bilinmeyen 18 kadın (\%5.4) vardır.

İşlenen cinayetlerin nedenlerine bakıldığında, kadınların \%37.3'ünün (125 kadın) tartışma yüzünden öldürüldüğü görülmektedir. Kadınların 38'i (\%11.3) kıskançlık ve eşini aldattığı şüphesi, 37 kadın (\%11) boşanmayı ya da ayrılmayı talep etmesi nedeniyle, 18 kadın (\%5.4) eski eşinin barışma talebini ya da kendisine gelen ilişki talebini reddettiği için öldürülmüştür. Ayrıca kadınların 13'ü (\%3.9) başka bir kadını korurken, 25'i (\%7.5) töre ve namus, 3'ü (\%0.9) tecavüze direnmesi nedeniyle öldürülmüştür. Kadınların 3'ü (\%0.9) nefret cinayetine kurban gitmiştir. Failin cinnet geçirmesi sonucu 2 kadının $(\% 0.6)$ öldürüldüğü belirtilmektedir. Cinayetlerin \%21.2'sinin $(n=71)$ neden işlendiğine dair bilgiye gazete haberlerinde yer verilmemiştir.

Cinayette kullanılan araçlar incelendiğinde, kadınların \%51.9'unun $(n=174)$ ateşli silah, \%35.8'inin $(n=120)$ kesici veya vurucu alet, \%0.3'ünün $(n=1)$ elektrik akımı kullanılarak öldürüldüğü görülmektedir. Bunlar dışında kadınların \%6.9'u $(n=23)$ boğularak, \%4.2'si $(n=14)$ dayakla, \%0.9'u $(n=3)$ ise yüksek bir yerden itilerek öldürülmüştür. $\mathrm{Bu}$ veriler kadınların öldürülmek kastıyla darp edildiği ya da şiddete maruz kaldığına işaret etmektedir.

\section{TARTIŞMA}

Kadın cinayetlerinin sayısı yıldan yıla artmaktadır. Araştırmanın bulguları incelendiğinde, Ocak 2014 ile Nisan 2015 tarihleri arasında, toplam 335 kadının erkekler tarafından öldürüldüğü görülmektedir. $\mathrm{Bu}$ cinayetlerin 266's1 2014 yılına, 69'u 2015 yilının sadece ilk üç ayına aittir. Anıt Sayaç'taki (2015) geçmiş yıllara ait kadın cinayetlerine dair veriler incelendiğinde, bu rakamın 2008 yılında 66, 2011 yılında 125, 2014 yılında ise 286 olduğu görülmektedir (www.anitsayac.com). Ayrıca "Kadın Cinayetleri- 
ni Durduracağız Platformu"nun (2013) internet sitesinde yer alan, 2008-2012 y1lları arasında erkekler tarafından işlenmiş kadın cinayetlerinin resmi olmayan basın taraması verilerinin sunulduğu bir dosyada, 2008 yılında 80 kadının, 2010 yılında 180 kadının, 2012 yılında ise 210 kadının hayatını kaybettiği sonucuna ulaşılmıştır (Kadın Cinayetlerini Durduracağı Platformu, 2013). Cumhurbaşkanlığı Devlet Denetleme Kurulu'nun 2013 yılında yayınladığı raporda da belirtildiği gibi, kadına yönelik şiddetin nedeni, boyutu ve yaygınlığı konusundaki istatistikler düzenli değildir. Ayrıca toplanan verilerin kurumlar açısından farklılık arz etmesi ve zaman serisi oluşturulmaması sağlıklı analizler yapmanın önünde engel olarak yer almaktadır (Cumhurbaşkanlığı Devlet Denetleme Kurulu, 2013). Her ne kadar bu konuda sağlıklı veriler olmasa da yukarıda yer alan rakamlar incelendiğinde kadına yönelik şiddetin en ağır hali olan kadın cinayetlerinin yıldan yıla artış gösterdiği sonucuna ulaşılabilmektedir. Ancak burada göz önünde bulundurulması gereken noktalardan biri, bu verilerin internet üzerinden geçmişe yönelik taramalar sonucu elde edilmiş olması ve tüm haberlere ulaşılamamış olma ihtimalidir. Bir diğeri ise bu süreçte işlenen cinayetlerin tümünün basına yansımamış olabileceğidir.

Bu çalışmada Ocak 2014 ile Nisan 2015 tarihleri arasında işlenmiş olan kadın cinayetlerinde fail ve maktulün sosyodemografik özellikleri (fail ve maktulün yaşı, mesleği, failin ruhsal bozukluk ve geçmiş suç öyküsü), fail ve maktul arasındaki ilişki, cinayet nedenleri ve cinayette kullanılan araçlar ile bu cinayetlerin bölgelere göre dağılımı incelenmiştir. İlk olarak fail ve maktulün yaşı değerlendirildiğinde, kadınların \%42.3'ünün 20-34 yaşları arasında öldürüldüğü, faillerinse \%33.3'ünün 25-39 yaşları arasında olduğu görülmektedir. Ülkemizde yapılan diğer çalışmalarda da kadın cinayetlerinde en büyük risk grubunun kadınlar için 20-34 yaş (Çilingiroğlu ve Paksoy Erbaydar, 2016; Karbeyaz ve ark., 2013; Tütüncüler, Özer, Karagöz ve Beyaztaş, 2015), erkekler için 21-40 yaş (Toprak ve Ersoy, 2017; Y11maz ve ark., 2015) aralığ olduğu görülmektedir. İspanya'da yapılan bir çalışmada da genç yaşta olmak kadın cinayetleri için risk faktörü olarak karşımıza çıkmaktadır (Echeburúa, Fernández-Montalvo, de Corral, P. ve López-Goñi, 2009). Kadın cinayetinin, şiddetin ulaştığı en son nokta olduğu ve cinayet kurbanlarının çoğu zaman öncesinde şiddete maruz kaldıkları göz önünde bulundurulduğunda aile içi şiddet araştırma sonuçları da önem kazanmaktadır. Türkiye'de Kadına Yönelik Aile İçi Şiddet Araştırması sonuçlarında, bizim çalışmamızla çelişen bir bulgu olarak, kadınların yaşı ilerledikçe yaşamları boyunca aile içinde fiziksel veya cinsel şiddete uğramış olma olasılığının arttığı belirtilmektedir (KSGM, 2009). Ancak söz konusu son 12 ay içerisinde maruz kalınan şiddet olduğunda, en fazla 15-34 yaş arasındaki (\%37.8) kadınların şiddet mağduru olduğu görülmektedir (KSGM, 2009). Buradan hareketle, kadınların daha genç yaşlarda ve evliliklerinin ilk yıllarında daha fazla şiddete maruz kaldıkları, bunun öldürülmeye kadar gidebildiği, dolayısıyla yaşın genç olmasının kadın cinayetleri için önemli bir risk faktörü olduğu söylenebilmektedir.

Tablo 3. Fail ve maktul arasındaki ilişki, cinayet nedeni ve cinayette kullanılan araçlara ilişkin frekans ve yüzde değerleri

\begin{tabular}{lcc}
\hline & $\mathrm{n}$ & $\%$ \\
\hline Maktul ve fail arasındaki ilişki & & \\
$\quad$ Partneri & 218 & 65.1 \\
Akrabası veya hısımı & 70 & 20.9 \\
Diğer & 47 & 14.0 \\
Cinayet nedeni & & \\
$\quad$ Tartışma & 125 & 37.3 \\
Kıskançlık/ Aldatma şüphesi & 38 & 11.3 \\
Kadının boşanmayı/ ayrılmayı & 37 & 11.0 \\
talep etmesi & & \\
Kadının barışma talebini/ ilişki & 18 & 5.4 \\
talebini reddetmesi & & \\
Kadın diğer bir kadını & 13 & 3.9 \\
korumaya çalışırken & & \\
Namus/ töre & 25 & 7.5 \\
Tecavüze direnmek & 3 & 0.9 \\
Nefret cinayeti & 3 & 0.9 \\
Failin cinnet geçirmesi & 2 & 0.6 \\
Bilinmiyor & 71 & 21.2 \\
& & \\
Cinayette kullanılan araç & & \\
Ateşli silah & 174 & 51.9 \\
Kesici/ vurucu alet & 120 & 35.8 \\
Boğma & 23 & 6.9 \\
Dayak & 14 & 4.2 \\
Elektrik Akımı & 1 & 0.3 \\
Yüksek bir kattan atma & 335 & 0.9 \\
Toplam & & \\
\hline
\end{tabular}

Çalışmada ele alınan bir başka değişken ise faillerin ve maktullerin meslekleridir. Pek çok gazete haberinde eğitim durumu ve mesleğe yer verilmediğinden, basından ulaşılabilen veriler oldukça kısıtlı olsa da bazı çıkarımlar yapmaya olanak sağlamaktadır. Faillerin \%73.3'ünün, maktullerinse \%81.8'inin çalışma durumuna ulaşılamamıştır. $\mathrm{Bu}$ oran oldukça yüksek olmakla birlikte, bu bilgilere ulaşılamaması fail ve maktullerin çalışmıyor olabileceğini, bununla paralel olarak gelir ve eğitim düzeyinin de düşük olabileceğini akla getirmektedir. Araştırmada çalışma durumu belirtilmiş olan fail ve maktullerin büyük çoğunluğunun (failler için \%18.7, maktuller için \%10.8) iş̧̧i olduğu, çok küçük bir grubunsa (failler için \%0.9, maktuller için \%3.6) üniversite eğitimi gerektiren mesleği olduğu göz önünde bulundurulduğunda, hem fail hem maktul için eğitim ve sosyoekonomik düzeyin düşük olması risk faktörü olarak 
yorumlanabilir. Yurtiçi ve yurtdışında yapılmış çalışmalarda da eğitim seviyesinin düşük olması, işsizlik ve düşük gelire sahip olmak kadın cinayetlerinde önemli risk faktörleri olarak belirtilmektedir (Campbell ve ark., 2003; Karbeyaz ve ark., 2013; Toprak ve Ersoy, 2017). Bu risk faktörleri kadına yönelik aile içi şiddete ilişkin alanyazında da vurgulanmaktadır. Türkiye'de Kadına Yönelik Aile İçi Şiddet Araştırması sonuçlarına göre, eğitim düzeyinin yükselmesi kadınların fiziksel, cinsel ve duygusal aile içi şiddete maruz kalma oranını düşürürken, ailenin refah düzeyinin artması kadınların şiddet yaşama olasılıklarını azaltmaktadır (KSGM, 2009). Şenol ve Yıldız'ın (2013) kadın ve erkek bakış açılarıyla kadına yönelik şiddet algısını inceledikleri çalışmada, ekonomik nedenlerle aile içi şiddete uğradığını belirten kadınların en büyük grubu oluşturduğu saptanmıştır. $\mathrm{Bu}$ gruptaki kadınlar, ekonomik sıkıntıları olmasa eşlerinin kendilerine şiddet uygulamayacağını, bu sıkıntılar yüzünden "istemeden" kendilerine şiddet uyguladıklarını ifade etmektedirler. Aile gelir ve refahının düşük olması ve bunun şiddet uygulamak için geçerli bir neden olarak içselleștirilmesinin, kadınların her tür şiddete maruz kalmaya devam etmelerine neden olduğu düşünülmektedir.

$\mathrm{Bu}$ çalışmada ruhsal bozukluğu olan faillerin oranı \%3 olarak bulunmuştur. Ülkemizde yapılan çalışmalarda da bu oran oldukça düşük bulunmakla birlikte (Toprak ve Ersoy, 2017; Y1lmaz ve ark., 2015), alanyazında ruhsal bozukluğun olması ile alkol ve uyuşturucu madde kullanmak kadın cinayetlerinde önemli bir risk faktörü olarak değerlendirilmektedir (Campbell, Glass, Sharps, Laughon ve Bloom, 2007). Ülkemizde psikiyatrik yardım ulaşılması zor olabildiği gibi toplum içerisinde damgalanma riskini de beraberinde getirmektedir. Bu nedenle psikiyatrik yardıma ihtiyacı olan bireyler tanı ve tedavi sürecine başvurmuyor olabilirler. $\mathrm{Bu}$ durum hem faillerin ruhsal bozuklukları konusunda doğru bulgulara ulaşmamızı engellerken, şiddet ve cinayet suçlarının artmasının da yolunu açıyor olabilir. Faillerin geçmiş suç öyküleri incelendiğinde, yine küçük bir grubun (\%7.2) geçmişte suç davranış1 olduğu, ancak ülkemizde yapılan çalışmalarda bu oranın daha yüksek bulunduğu görülmektedir (Toprak ve Ersoy, 2017; Tütüncüler ve ark., 2015). Bu çalışmalarda adli otopsi raporu gibi yasal evraklar üzerinden değerlendirme yapılması, ancak bizim çalışmamızda gazete haberlerinin içerik analiziyle bu bulguya ulaşılması oranlar arasında fark olmasında etkili olabilir.

Çalı̧̧mada kadınların büyük çoğunluğunun (\%65.1) eşi ya da eski eşi (resmi nikâhlı eşi, eski eşi, dini nikâhlı eşi, nişanlısı, eski nişanlısı, sevgilisi, eski sevgilisi) tarafından öldürüldügü bulunmuştur. $\mathrm{Bu}$ bulgu alanyazındaki araştırma sonuçlarıyla tutarlıdır. Stöckl ve arkadaşları (2013) yaptıkları kapsamlı çalışmada kadınların büyük çoğunluğunun (\%38) eşi ya da eski eşi tarafından öldürüldüğünü bulmuştur. Ülkemizde yapılmış çalışmalarda, araştırma sonucuyla tutarlı olarak bu oranın çok yüksek olduğu ve \%50 ile \%78.2 aralığında değiştiği görülmektedir (Çilingiroğlu ve Paksoy Erbaydar, 2016; Toprak ve Ersoy, 2017; Yegen, 2014).

Çalışmada kadın cinayeti işlenme nedeninin sıklikla tartışma olduğu bulunmuştur, ancak gazete haberlerinin içerik analizi, tartışma nedenlerini belirlemede yetersiz kalmıştır. Atakay (2014) da çalışmasında bizim araştırma bulgumuzla tutarlı olarak kadın cinayetlerinde en önemli neden olarak tartışma ve kavgaları bulmuştur. Fail ve maktullerin çoğunlukla düşük eğitim ve gelir düzeyine sahip bireyler olduğu göz önünde bulundurulduğunda, tartışmaların refah düzeyi düşük olan ailelerde ekonomik nedenlerden yaşanıyor olabileceği düşünülebilir. Karbeyaz ve ark., (2013) kadın cinayetlerinde önemli bir neden olarak ekonomik sorunlara işaret etmektedir. Ataerkil toplum özelliğinde erkekler, evin geçimini sağlama konusunda sorumluluk hissettiğinden, ailenin gelir seviyesinin düşmesi, erkekte yetersizlik algısına yol açarak, tüketici konumunda gördüğü kadına şiddet uygulamasina neden olabilmektedir. Şiddet uygulamak, erkeklerin kendilerini rahatlatarak hâkimiyet duygusunu fiziksel olarak devam ettirmelerini sağlamaktadır (Şenol ve Yıldız, 2013). Mevcut çalışmada cinayetlerin tartışma dışında sıklıkla kıskançlık, aldatma şüphesi, kadının ayrılmayı talep etmesi ile töre ve namus nedenlerinden işlendiği bulunmuştur. Kadin cinayetlerinin bu nedenlerden işlendiğini söyleyen çalışma bulguları alanyazında da mevcuttur (Atakay, 2014; Campbell ve ark., 2003; Echeburúa, Fernández-Montalvo, de Corral, P. ve López-Goñi, 2009; Karbeyaz ve ark., 2013). Bu bulgular bir arada değerlendirildiğinde, ekonomik sıkıntıların yanı sıra erkek egemen düzenin kadına yönelik şiddette çok önemli bir faktör olduğu bir kez daha doğrulanmaktadır. Ataerkil düzen doğrultusunda ailesi için çalışan ve para kazanan, güçlü ve cesur erkeklerin kadının kendi başına bir birey olması ve hayatını istediği yönde sürdürmesi söz konusu olduğunda ailesini korumak adına şiddete başvurduğu görülmektedir (Taşdemir Afşar, 2016). Kadına yönelik şiddet alg1sının incelendiği bir çalışmada erkeklerin şiddet uygulama nedeni olarak eşlerinin saygısız davranmalarını gösterdikleri, şiddeti hak ettiklerini düşündükleri, evin reisi olarak ailelerinin daha iyi şartlarda yaşamas1 için bunu yaptıklarını ifade ettikleri bulunmuştur (Şenol ve Yıldız, 2013). Şiddet, erkeklerin kadınlar üzerindeki gücünü sürdürmek ve cinsiyet eşitsizliğini pekiştirmek için kullandıkları bir araç gibi görünmektedir (Taşdemir Afşar, 2016).

$\mathrm{Bu}$ çalışmada kadın cinayetlerinin en sık işılendiği yer olarak karşımıza İstanbul çıkmaktadır. İstanbul'un çok fazla göç aldığı düşünüldüğünde, göç olgusunun ve göçten kaynaklanan sorunların bu 
Konuda etkisinin olduğu ihtimaller dâhilindedir. Özellikle barınma olanaklarının yetersiz olması, eğitimsizlik, yoksulluk, kalabalık aileler gibi faktörler ve bütün bunların sonucu olarak kadın cinsiyet rolleri üzerine odaklanan geleneksel zihniyetin katılaşması cinayetlerin ortaya çıkmasında etkili olabilmektedir. Diğer bir deyişle, bu cinayetler erkek egemen, ataerkil sistemin sürdürülmesini sağlamaktadır (TBMM Komisyon Çalışmaları, 2005). Son olarak, bu çalı̧̧mada alanyazınla tutarlı olarak cinayetlerin büyük çoğunluğunun ateşli silahla işlendiği sonucuna ulaş1lmıştır (Campbell ve ark., 2003; Toprak ve Ersoy, 2007). Failin ateşli silah sahibi olmasının kadın cinayetlerinde en önemli risk faktörlerinden olduğu bilinmekle birlikte, Türkiye'de ateşli silahlara ulaşımın nispeten kolay olduğu düşünülmektedir.

$\mathrm{Bu}$ çalışmada elde edilen sonuçlar, pek çok çalışmada olduğu gibi çeşitli sınırlılıkları beraberinde getirmektedir. Çalışmanın verilerinin gazete haberlerine dayanması sinırlılıklardan biridir. Bu yöntem, kadın cinayetlerini içeren tüm haberlere ulaşılamamış olma ve tüm cinayetlerin basına yansımamış olma olasılığını düşündürmektedir. Ayrıca fail ve maktullerin eğitim düzeyi, ekonomik düzeyi, çalışma duru$\mathrm{mu}$, ruhsal bozukluğu ve geçmiş suç davranışlarına ilişkin bilgilere kapsamlı olarak ulaşılamamıştır. $\mathrm{Bu}$ bağlamda polis kayıtları, otopsi raporları, mahkeme dosyaları ve hastane kayıtlarını içeren resmi evrakların bir arada değerlendirildiği, ülke genelinde bir çalışmanın yapılmasının kadın cinayetlerinde risk faktörlerini kapsamlı olarak belirlemede önemli olacağı düşünülmektedir.

\section{Sonuç ve Öneriler}

Kadın cinayetlerinde eğitimsizlik, ekonomik sıkınt1lar, ataerkil toplum özelliği ve ateşli silah sahibi olmak önemli risk faktörleri olarak karşımıza çıkmaktadır. Bu bağlamda kadının aldığı eğitim doğrultusunda ekonomik bağımsızlığını kazanmasının ve kendini ifade edip haklarını savunabilir hale gelmesinin, sosyoekonomik açıdan güçlenmesinin şiddet ve cinayetler üzerinde önemli bir koruyucu faktör olacağ1 düşünülmektedir. Bunun için uzun vadede eğitim olanaklarının geliştirilmesinin yanı sıra kısa vadede kadınların iş sahibi olmasının yolunun açılması önemli görünmektedir. Kadına yönelik şiddet ve kadın cinayetlerinde gözden kaçırılmaması gereken noktalardan biriyse aynı risk faktörlerinin şiddet uygulayıcıları ve failler için de geçerli olduğudur. $\mathrm{Bu}$ nedenle toplum düzeyinde eğitim ve iş olanaklarının geliştirilmesi, cinsiyet ayrımı gözetmeksizin istihdamın sağlanması önemli görünmektedir. Bu istihdam sağlanırken, cinayetlerin yoğunlukla işlendiği bölgelere hassasiyetle yaklaşılması ve bu bölgelere daha çok istihdamın sağlanması da dikkat edilmesi gerekenler arasındadır.
Kadına yönelik şiddet ve kadın cinayetlerini engellemek adına atılabilecek adımlardan bir diğeri eğitimle ilişkilidir. Kadınların kendi haklarını tanımaları ve kendi bağımsızlıkları konusunda bilgilendirilmeleri, yanı sıra erkeklerin kadın hakları konusunda bilinçlendirilmesi adına eğitim almaları önemli görülmektedir. Söz konusu eğitimler kadının toplumdaki yerini anlaması ve haklarına sahip çıkmasını sağlarken, erkeğin de kadının toplumdaki yerini kabullenmesi adına temel oluşturacaktır. Ayrıca hem kadın hem erkekler için öfke kontrolünün ve iletişim becerilerinin geliştirilip, duygu ve düşüncelerin paylaşılabildiği alternatif çatışma çözme yöntemlerinin öğretildiği zeminlerin yaratılmasının şiddet ve cinayetlerin azalmasında etkili olabileceği düşünülmektedir. Kadın cinayetlerinde önemli bir nokta, ateşli silah sahibi olmanın yaygın olmasıdır. Bu noktada ateşli silah sahibi olmanın zorlaştırılması, özellikle geçmiş suç öyküsü olan bireylerin ulaşımının kısıtlanması önemli bir tedbirler arasında yer alabilir. Son olarak, kadın haklarının yanı sıra temelde insan haklarının ihlali olan bu konuda kadın erkek eşitsizliğinin önüne geçilebilmesi için şiddete maruz kalan bireylerin başvurabileceği hukuki yolların farkındalığına ek olarak, psikolojik destek alabilecekleri kurumlara dair farkındalıklarının arttırılması da etkili olabilir. $\mathrm{Bu}$ noktada ruh sağlığı çalışanlarına önemli görevler düşmektedir. Ruh sağllğ çalışanının öncelikle ülkemizde kadına yönelik aile içi şiddetin yaygınlığının ve bunun kadın cinayetleri için önemli bir risk faktörü olduğunun farkında olması gerekmektedir. $\mathrm{Bu}$ bağlamda psikolojik yardım sürecinde şiddet yaşantısından söz edilmese bile hem kadın hem erkek dan1şanın şiddet mağduru ya da uygulayıcısı risk grubunda olup olmadığının değerlendirilmesi ve bu bağlamda bilgi almaya açık olması gerekmektedir. Eğer kadın şiddet mağduruysa atabileceği hukuki adımlar konusunda ruh sağlığı çalışanının bilgi sahibi olması ve bu süreçte ona psikolojik yardım sağlamaya devam etmesi önemli görünmektedir. Ayrıca aile içi şiddet varsa, evde silah olup olmadığının sorgulanmas1 ve bunun olas1 riskleri hakkında da bilgilendirme yapılması gerekmektedir. Son olarak bu süreçte hem kadın hem erkek danışanın sosyal destek ağlarının geliştirilmesine çalışılması da ruh sağlığı çalışanına düşen görevlerdendir.

\section{KAYNAKLAR}

Adinkrah, M. (2008). Spousal homicides in contemporary Ghana. Journal of Criminal Justice, 36, 209-216.

Alhabib, S., Nur, U. ve Jones, R. (2010). Domestic violence against women: Systematic review of prevalance studies. Journal of Family Violence, 25, 369-382.

Anıt Sayaç. (2015). Şiddetten Ölen Kadınlar İçin Dijital Anit.1-30 Nisan 2015, http://anitsayac.com/?year=2014

Ankara Barosu Kadın Hakları Merkezi. (2008). Kadın haklarl el kitabl. 15 Temmuz 2015, 
http://www.ankarabarosu.org.tr/Siteler/19402010/Kitap lar/pdf/k/kadin2008.pdf

Atakay, C. (2014). Romantik yakın ilişkilerde şiddetin öncülleri. Nesne, 2(3), 1-9.

Babu, B.V. ve Kar, S.K. (2009). Domestic violence against women in eastern India: a population-based study on prevalence and related issues. BMC Public Health 9 (129), 1-15.

Caetano, R., Schafer, J. ve Cunradi, C.B. (2001). Alcoholrelated intimate partner violence among white, black, and Hispanic couples in the United States. Alcohol Research and Health, 25 (1), 58-65.

Caetano, R., Vaeth, P.A.C. ve Ramisetty-Mikler, S. (2008). Intimate partner violence victim and perpetrator characteristics among couples in the United States. Journal of Family Violence 23, 507-518.

Campbell, J.C., Glass, N., Sharps, P.W., Laughon, K., ve Bloom, T. (2007). Intimate partner homicide: review and implications of research and policy. Trauma, Violence, \& Abuse, 8(3), 246-269.

Campbell, J.C., Webster, D., Koziol-McLain, J., Block, C., Campbell, D., Curry, M.A., ... Sharps, P. (2003). Risk factors for femicide in abusive relationships: Results from a multisite case control study. American journal of public health, 93(7), 1089-1097.

Caputi, J. ve Russell, D.E.H. (1990). Femicide: Speaking the unspeakable. Ms. 1, (2), 424-431.

Cumhurbaşkanlığı Devlet Denetleme Kurulu (2013). Merkezi ve yerel kamu kurum ve kuruluşlar ile sivil toplum kuruluşlarının, kadın ve çocuklara yönelik şiddetle $m$ cadele kapasite ve imkanlarının değerlendirilmesi raporu. 3 Ocak 2016, https://www.tccb.gov.tr/assets /dosya/ddk55.pdf

Çilingiroğlu, N. ve Paksoy Erbaydar, N. (2016). Intimate partner violence: Turkey's femicide problem. Injury prevention, 22, A143.

Dery, D. ve Diedong, A.L. (2014). Domestic violence against women in Ghana: An exploratory study in Upper West Region, Ghana. International Journal of Humanities and Social Science, 4 (12), 228-244.

Ehrensaft, M.K., Cohen, P., Brown, J., Smailes, E., Chen, H. ve Johnson, J.G. (2003). Intergenerational transmission of partner violence: A 20-year prospective study. Journal of Consulting and Clinical Psychology, 71(4), 741-753.

Echeburúa, E., Fernández-Montalvo, J., de Corral, P. ve López-Goñi, J. J. (2009). Assessing risk markers in intimate partner femicide and severe violence: A new assessment instrument. Journal of Interpersonal Violence, 24(6), 925-939.

Fals-Stewart, W.F. (2003). The occurrence of partner physical aggression on days of alcohol consumption: A longitudinal diary study. Journal of Consulting and Clinical Psychology, 71 (1), 41-52.

Foran, H. M. ve O'Leary, K. D. (2008). Alcohol and intimate partner violence: A meta analytic review. Clinical Psychology Review, 28 (2008), 1222-1234.

Heise, L.L. (1998). Violence against women an integrated, ecological framework. Violence against women, 4 (3), 262-290.

Kadın Cinayetlerini Durduracağız Platformu (2013). 20082012 kadın cinayeti gerçekleri. 20 Ağustos 2015, http://kadincinayetlerinidurduracagiz.net/veriler/273/20 08-2012/kadin-cinayeti-gercekleri

Kadının Statüsü Genel Müdürlüğü (2008). Aile içi şiddetle mücadele el kitabı. Ankara: Başbakanlık Kadının Statüsü Genel Müdürlüğü Yayınları.

Kadının Statüsü Genel Müdürlüğü (2009). Türkiye’de kadına yönelik aile içi şiddet. Ankara: Başbakanlık Kadının Statüsü Genel Müdürlüğü Yayınları.

Kadının Statüsü Genel Müdürlüğü (2013). Kadına yönelik şiddetle mücadele el kitabı. Ankara: Başbakanlık Kadının Statüsü Genel Müdürlüğü Yayınları.

Kadının Statüsü Genel Müdürlüğü (2015). Türkiye’de kadına yönelik aile içi şiddet. Ankara: Başbakanlık Kadının Statüsü Genel Müdürlüğü Yayınları.

Karbeyaz, K., Akkaya, H., ve Balci, Y. (2013). An analysis of the murder of women in a 10-year period in Eskişehir Province located in western Anatolia in Turkey. Journal of forensic and legal medicine, 20(6), 736-739.

Lengerli, A. (2010). Eş şiddeti suçu ile ilişkili olabilecek psiko-sosyal faktörlerin belirlenmesi ve suç analizi (Yayınlanmamıș yüksek lisans tezi). Ankara Üniversitesi Sağlık Bilimleri Enstitüsü, Ankara.

Leonard, K.E. ve Quigley, B.M. (1997). Drinking and marital aggression in newlyweds: An event-based analysis of drinking and the occurrence of husband marital aggression. Journal of Studies on Alcohol, 60 (4), 537-545.

Özgentürk, I. (2015). Physical intimate partner violence against women in Turkey. European Scientific Journal, $11(2), 54-69$.

Padney, A. ve Nath, D.C. (2014). Corraletes of domestic violence in India. GSTF Journalof Law and Social Sciences, 4 (1), 1-10.

Page, A. Z. ve İnce, M. (2008). Aile içi şiddet konusunda bir derleme. Türk Psikoloji Yazılarl, 11 (22), 81-94.

Puzone, C.A., Saltzman, L.E., Kresnow, M., Thompson, M.P. ve Mercy, J.A. (2000). National trends in intimate partner homicide. Violence Against Women, 6 (4), 409426.

Russell, D.E.H. (2008). Femicide: Politicizing the killing of females. Strengthening Understanding of Femicide: Using Research to Galvanize Action and Accountability, Washington DC.Sharps, P.W., Koziol-McLain,J., Campbell, J., McFarlane, J., Sachs, C. ve Xu, X. (2001).

Health care providers' missed opportunities for preventing femicide. Preventive Medicine, 33, 373-380.

Stöckl, H., Devries, K., Rotstein, A., Abrahams, N., Campbell, J., Watts, C., ve Moreno, C. G. (2013). The global prevalence of intimate partner homicide: a systematic review. The Lancet, 382(9895), 859-865.

Straus, M.A. ve Gelles, R.J. (2006). Behind closed doors: Violence in the American family (Transaction ed.). New York: Taylor \& Francis.

Şenol, D. ve Yıldız, S. (2013). Kadına yönelik şiddet alglsı: Kadın ve erkek bakış açılarıyla. Ankara: Mutlu Çocuklar Derneği Yayınları.

Taşdemir Afşar, S. (2016). Violence against women and femicides in Turkey. European Journal of Multidisciplinary Studies (2), 1, 70-80.

Toprak, S. ve Ersoy, G. (2017). Femicide in Turkey between 2000- 2010. PloS ONE, 12(8), e0182409. 
Türkiye Büyük Millet Meclisi Komisyon Çalışmaları (2005). Töre ve namus cinayetleri ile kadınlara ve çocuklara yönelik şiddetin sebeplerinin araştırlarak alınmasi gereken önlemlerin belirlenmesi amacıla kurulan (10/148, 182, 187, 284, 285 ) esas numarall Meclis Araștırması Komisyonu raporu. 10 Temmuz 2015, http://kadininstatusu.aile.gov.tr/data/542a8e0b369dc31 550b3ac30/tbmmkom/bolum1.pdf

Tütüncüler, A., Özer, E., Karagöz, Y. M., ve Beyaztaş, F. Y. (2015). Evalution of Femicide Cases Committed Between the Years 1996-2005 in Antalya. OMEGAJournal of death and dying, 71(2), 198-210.

World Health Organization (2005). WHO Multi-country Study on Women's Health and Domestic Violence against Women. Geneva: WHO. 15 Ağustos 2015, http://www.who.int/reproductivehealth/publications/vio lence/24159358X/en/

World Health Organization. (2012). Understanding and addressing violence against women: femicide. 30 Ağustos 2018, http://apps.who.int/iris/bitstream/handle/ 10665/77421/WHO_RHR_12.38_eng.pdf;jsesionid=09 5A881B40DA4E1E0914F1BDD3EEC571? sequence=1

World Health Organization (2013). Global and regional estimates of violence against women: prevalence and health effects of intimate partner violence and nonpartner sexual violence. Geneva: WHO. 15 Ağustos 2015, http://apps.who.int/iris/bitstream/10665/85239/1/ 9789241564625_eng.pdf?ua=1

Wormer, V.K. ve Roberts, R.A. (2009). Death by Domestic violence: Preventing the murders and murdersuicides (Social and psychological issues: Challenges and solutions). Connecticut: Greenwood Publishing Group.

Yaman Efe, Ş. ve Ayaz, S. (2010). Kadına yönelik aile içi şiddet ve kadınların ile içi şiddete bakışı. Anadolu Psikiyatri Dergisi 11, 23-39.

Yegen, C. (2014). İnternet haberciliğinde kadın cinayeti haberlerinin sunumu: Posta gazetesi örneği. The Turkish Online Journal of Design, Art and Communication, 4 (3), 15-28.

Yılmaz, E., Kumral, B., Cantürk, N., Erkol, Z., ve Okumuş, A.M. (2015). Analysis and comparison of domestic femicide cases in the cities of Diyarbakir \& Tekirdag, Turkey: A preliminary study. Journal of forensic and legal medicine, 34, 17-23. 